\title{
EVALUATION PERFORMANCE OF THREE Pennisetum GENUS GROWN ON PINES FOREST IN LEMBANG, WEST JAVA
}

\author{
Sajimin and N. D. Purwantari \\ Indonesian Research Institute for Animal Production, P.O. Box 221 Ciawi-Bogor \\ Balai Penelitian Ternak Jalan Veteran III Banjarwaru Ciawi Bogor Jawa Barat \\ Email: djiemin@yahoo.com
}

\begin{abstract}
Pines are the largest tree forests in West of Java so that they are very potential to be developed as an agroforestry system. Forage crop potentially to be cultivated in the agroforestry system. The aim of the research was to study the response of the grasses grown under pines forest. The experiment was conducted at pines forest area arranged in randomized complete block design. The treatments were 3 grasses (Pennisetum purpureum cv. Taiwan, P. purpureum (local) and Pennisetum purpureophoides (king grass). Data collected were productivity, agronomic performance (plant height, tiller), forage production and quality. The result shows that shoot production of Taiwan cultivar was significantly higher than local $P$. purpureum. It was produced $498.4 \mathrm{~g} /$ clump on rainy season and $287.0 \mathrm{~g} /$ clump at dry season. At dry season forage production was decreased by $39,9 \% /$ ha. Nutrient composition at rainy season, crude fibre of grass was $39.89 \%$; Ca $0.04 \%$; P 0.26\%; ash 12.46\%; energy $4239.5 \mathrm{kcal} / \mathrm{kg}$ and crude protein $8.23 \%$; while at the mid of dry season crude fibre was 38.43\%; Ca 0.035\%; P 0.26\%; ash 11,43\%; energy $3943 \mathrm{kcal} / \mathrm{kg}$ and crude protein 8.94\%.
\end{abstract}

Key word: pines, forestry, forage, production, quality

\section{EVALUASI PERFORMAN TIGA JENIS RUMPUT Pennisetum sp DI BAWAH TEGAKAN TANAMAN PINUS DI LEMBANG JAWA BARAT}

\begin{abstract}
ABSTRAK
Tanaman pinus di Jawa Barat cukup besar dan sangat potensial untuk pengembangan sistem agroforestry. Tanaman pakan ternak untuk dibudidayakan pada sistem agroforestry sangat potensial. Penelitian ini untuk mempelajari respon rumput gajah di bawah tanaman pinus. Rancangan percobaan acak kelompok dengan perlakuan rumput gajah lokal (Pennisetum purpureum local), rumput raja ( $P$. purpureophoides) dan rumput gajah Taiwan ( $P$. purpureum cv Taiwan) dengan lima ulangan masing-masing ditanam dengan ukuran plot $100 \mathrm{~m} 2$. Interval potong delapan minggu dan pengumpulan data meliputi produksi dan kualitas hijauan, performan agronomi (tinggi tanaman, jumlah tunas). Hasil penelitian menunjukkan bahwa produksi tunas rumput gajah Taiwan nyata lebih tinggi daripada rumput gajah lokal. Produksi hijauan per rumpun 498,4 g pada musim hujan dan 287,o g pada musim kering. Produksi hijauan pada musim kering menurun 39,9\%/ha. Kandungan nutrisi pada musim hujan serat kasar adalah 39,89\%, Ca 0,04\%; P 0,26\%, Abu 12,46\%; energi $4239,5 \mathrm{kcal} / \mathrm{kg}$ dan protein kasar 8,23\%. Sedangkan pada pertengahan musim kering serat kasar 38,43\%; Ca 0,035\%; P o,26\%; abu 11,43\%; energy $3943 \mathrm{kcal} / \mathrm{kg}$ dan protein kasar 8,94\%.
\end{abstract}

Kata kunci: hutan pinus, tanaman pakan ternak, produksi, kualitas

\section{INTRODUCTION}

Forage is the most component of feed in ruminant. Therefore, the quantity, quality and availability of forage is crucial for optimal livestock production. Area for forage production is decreasing since shift into other function. Some of forest area is one of alternative land available for forage production. Integration forest and forage crop need strategy in managing, so that symbiose mutualism occurred between two crops. Pines forest dominate forest in
West Jawa (Perhutani, 2002). Forest management by silvopasture system where perhutani, village people and other stakeholder collaborated in managing forest resources with balance, sustainable way.

Napier grass (Pennisetum purpureum Schum) also know as elephant grass, is a deep rooted high yielding, perennial grass that is native to eastern and Central Africa (Boonman, 1995, Nyambati et al., 2010). It grows in tropical and sub-tropical regions with a wide range of annual from $750-2500 \mathrm{~mm}$ rainfall and in altitudes ranging from sea level to altitudes of 
over $2100 \mathrm{~m}$. It is the most popular perennial fodder recommended for the intensively managed small holder crop-livestock farming system and it is well adapted in Indonesia. This grass has been cultivated by farmers widely as main source of forage for ruminant. However, their productivity was low at pines forest area and need to be improved. The development of crops in pines forest as agroforestry is affected by some limiting factors such as light intensity. Purnomo and Sitompul (2006) light intensity under pines is approximately $14 \%$ which is very low for plant growth.

The activity was to study the growth and production of forage crop grown at pines forest area to supply feed for dairy cattle around the location

\section{MATERIALS AND METHODS}

Experiment was conducted on pines forest in Lembang, Bandung, West Java. Based on Schmith and Ferguson (1951), climate at the location is A type. Average rainfall $2.996 \mathrm{~mm} / \mathrm{yr}$. Topografy hilly, altitude is $1500 \mathrm{~m}$ above sea level and dominant sloping $>25 \%$. Soil type is andosol, with high organic matter (Lembaga Penelitian Tanah, 1981). Three species of grasses were used in the experiment, i. e. Pennisetum purpureum cv Taiwan (elephant grass), Pennisetum purpureophoides (King grass) and Pennisetum purpureum (local) and plot size was 100 $\mathrm{m}^{2}$. Experimental design was randomized complete block design (RBD) and treatment was replicated 5 times.

Organic fertilizer was used 10 tons/ha and applied before planting. Stem of plant was used as planting material. At 30 days old after planting, anorganic fertilizer i. e. urea $100 \mathrm{~kg}$, TSP $50 \mathrm{~kg}$ and $\mathrm{KCl} 50 \mathrm{~kg}$ per ha were applied. Weeding was done manually after harvest if necessary. All the measurements were taken at eight weeks of regrowth, the recommended period for feeding the napier grass. Morphological characterization was determined by measuring plant growth habit characteristics from representative stools/tillers. Plant growth habbit was determined by measuring tiller number/stool, tiller height, shoot production and forage quality (crude protein, crude fiber, ash, energy, Ca, P). Quadrate sampling method was applied randomly to measure forage production.

\section{RESULTS AND DISCUSSION}

Plant height and number of tiller of grasses grown under pines forest is presented in Table 1 and 2 . The highest plant height was obtained by elephant grass cv Taiwan $(258.4 \mathrm{~cm})$ and significantly different with local elephant grass $(\mathrm{P}<0.05)$. All the grasses tested, their plant height was decreasing by season
(Table 1). The most decreasing of shoot production was elephant grass cv Taiwan $(258.4 \mathrm{~cm}$ to $72.0 \mathrm{~cm}$ ) and the lowest was local elephant grass $(198.4 \mathrm{~cm}$ to $121.0 \mathrm{~cm}$ ). The same pattern was occurred for number of tiller (Table 2).

Table 1. Plant height $(\mathrm{cm})$ genus of Pennisetum at different time of harvest

\begin{tabular}{lccc}
\hline \multicolumn{1}{c}{ Harvest time } & $\begin{array}{c}\text { P. purpureum cv. P. purpureophoi- } \\
\text { Taiwan }\end{array}$ & $\begin{array}{c}\text { P. purpureum } \\
\text { cv. Local }\end{array}$ \\
\hline End of rainy season & $211,7^{\mathrm{a}}$ & $200,4^{\mathrm{a}}$ & $198,4^{\mathrm{a}}$ \\
Mid of dry season & $258,4^{\mathrm{a}}$ & $217,5^{\mathrm{a}}$ & $176,3^{\mathrm{a}}$ \\
End of dry season & $72,0^{\mathrm{b}}$ & $80,5^{\mathrm{b}}$ & $121,0^{\mathrm{b}}$ \\
\hline
\end{tabular}

Value with the same alphabet at the same row is not significantly different $(P<0,05)$

Table 2. Number of tiller of three grasses

\begin{tabular}{lccc}
\hline \multicolumn{1}{c}{ Harvest time } & $\begin{array}{c}\text { P. purpureum } \\
\text { Cv. Taiwan }\end{array}$ & $\begin{array}{c}\text { P. purpureophoi- } \\
\text { des }\end{array}$ & $\begin{array}{c}\text { P. purpureum } \\
\text { cv. Local }\end{array}$ \\
\hline End of rainy season & $12.9^{\mathrm{b}}$ & $15.2^{\mathrm{b}}$ & $14.8^{\mathrm{b}}$ \\
Mid of dry season & $20.0^{\mathrm{a}}$ & $25.7^{\mathrm{a}}$ & $18.3^{\mathrm{a}}$ \\
End of dry season & $13.8^{\mathrm{b}}$ & $9.6^{\mathrm{b}}$ & $11.8^{\mathrm{b}}$ \\
\hline
\end{tabular}

Value with the same alphabet at the same row is not significantly different $(P<0,05)$

Table 2 at end of dry season the highest number of tiller was $P$. purpureum cv. Taiwan and significantly different with the other two grasses (Table 2). This result was lower than at end of rainy season and mid of dry season. This may due to the lack of water which then affect soil nutrient absorption by the root. Suwarna et al (1994) and Da Silveiraet al (2010) reported Panicum maximum grass decreasing in tiller number when lack of water. On the other hand, Bilal et al. (2001) found that P. purpureum cv. Mott produced more tiller when lack of water.

\section{Shoot Production}

Shoot production of local elephant grass was more stable during the experiment than other two grasses. Although shoot production of local elephant grass was the lowest than the other two grasses at rainy season. The local grass is more adapted to the agroclimate in where they have been grown and it has been cultivated by the farmers for longer time than the other two grasses (Table 3 and 4 ).

Tabel 3. Fresh shoot production (g/clump) three grasses

\begin{tabular}{lccc}
\hline Harvest time & $\begin{array}{c}\text { Pennisetum pur- } \\
\text { pureum } \\
\text { Cv. Taiwan }\end{array}$ & $\begin{array}{c}\text { P. purpureophoi- } \\
\text { des }\end{array}$ & $\begin{array}{c}\text { P. purpureum } \\
\text { CV. Local }\end{array}$ \\
\hline End of rainy season & 2608,3 & $2663,9^{\mathrm{a}}$ & $2336,1^{\mathrm{b}}$ \\
Mid of dry season & 2364,5 & $2178,0^{\mathrm{a}}$ & $1516,7^{\mathrm{ab}}$ \\
End of dry season & 1565,0 & $835,0^{\mathrm{b}}$ & $1900,0^{\mathrm{a}}$ \\
\hline
\end{tabular}

Value with the same alphabet at the same row is not significantly different $(P<0,05)$

At the end of dry season, $P$. purpureophoides significantly lowest shoot production was compared with two other grasses (Tablel 3 and 4). This result was lower shoot production compared to production 
Table 4. Dry weight (gram/clump) three grasses

\begin{tabular}{lccc}
\hline Harvest time & $\begin{array}{c}\text { Pennisetum pur- } \\
\text { pureum } \\
\text { cv. Taiwan }\end{array}$ & $\begin{array}{c}\text { P. purpureophoi- } \\
\text { des }\end{array}$ & $\begin{array}{c}\text { P. purpureum } \\
\text { Cv. Local }\end{array}$ \\
\hline End of rainy season & $498,4^{\mathrm{b}}$ & $506,1^{\mathrm{b}}$ & $448,5^{\mathrm{a}}$ \\
Mid of dry season & $456,3^{\mathrm{a}}$ & $413,8^{\mathrm{a}}$ & $290,8^{\mathrm{ab}}$ \\
End of dry season & $287,0^{\mathrm{a}}$ & $178,2^{\mathrm{b}}$ & $448,3^{\mathrm{a}}$ \\
\hline
\end{tabular}

Value with the same alphabet at the same row is not significantly different $(P<0,05)$

of grasses grown in unshaded area reported by Siregar 1991). Purnomo and Sitompul (2006) reported that light is important factor for plant growth, and also water and nutrient. Photosynthesis rate will be lower at low light intensity. Therefore, it will affect on biomass production.

Besides light intensity factor which inhibit plat gowrth, pines tree produce turpentine oil and secondary metabolit which have allelopathic character from terpenoid group containe penine and tannin (Taiz and Zeiger, 1991). Those compound are toxic for insect and inhibit other plant growth on pines tree area. This effect, it seems the low production of grasses in the study were lower than previous result.

From the three grasses observed, in end of rainy season to end of dry season, shoot production of local elephant grass was more stable. However, this grass was flowering earlier than the other two grasses. Therefore, the grass quality is quicker to dropped (Purwantari et al., 2009).

Table 5. Nutrient composition of 3 grasses at rainy season and dry season

\begin{tabular}{llcc}
\hline \multirow{2}{*}{ Grasses } & \multirow{2}{*}{ Nutrien content } & \multicolumn{2}{c}{ Harvest time } \\
\cline { 3 - 4 } & & Rainy season & Dry season \\
\hline P. purpureum cv. Taiwan & Crude proteinr (\%) & 7.16 & 10.92 \\
& Crude fiber (\%) & 40.04 & 40.28 \\
& Ca (\%) & 0.02 & 0.02 \\
& $\mathrm{P}(\%)$ & 0.25 & 0.30 \\
& Energy (kcal/kg) & 4404.00 & 4116.00 \\
P. purpureophoides & Crude proteinr (\%) & 8.19 & 9.75 \\
& Crude fiber (\%) & 37.02 & 43.43 \\
& Ca (\%) & 0.03 & 0.02 \\
& P(\%) & 0.24 & 0.23 \\
& Energy (kcal/kg) & 4185.00 & 3770.00 \\
P. purpureum cv. Local & Crude proteinr (\%) & 9.57 & 10.53 \\
& Crude fiber (\%) & 37.05 & 33.42 \\
& Ca (\%) & 0.03 & 0.03 \\
& P(\%) & 0.17 & 0.29 \\
& Energy (kcal/kg) & 4178.00 & 3905.00 \\
\hline
\end{tabular}

Table 5 shows the nutrient composition of those grasses grown under pines forest. At dry season nutrient content was higher than at rainy season on crude fiber, crude protein $(9.75-10.92 \%$ and $P$ (0.23-0.30\%). This could be the growth at the dry season was slow.

\section{CONCLUSION}

Pennisetum purpureum cv. Taiwan produced and $P$. purpureophoides were higher forage production under pines forest at end of rainy season. At end of dry season, $P$. purpureophoides was the lowest shoot production. $P$. purpureum cv. Local was flowering earlier that $P$. purpureum cv. Taiwan. $P$. purpureum cv. Taiwan is suggested to be grown under pines forest.

\section{REFERENCES}

Bilal MQ, Sarwar M and Ahmad S. 2001. Effect of stage of growth and nitrogen fertilization on protein contentsof Mott grass and its morphological fractions. International journal ofagriculture and biology. Vol 3(1): $39-41$.

Booman JG.1993. East Africa's grass and fodders : Their ecology and husbandry. In : Nyambati EM, Muyekho FN, Ongijo E and Luswiti CM, 2010. Production, Characterization and Nutritionla Quality of Napier grass cultivations in Western Kenya. African journal of plant Sci: 4 (12): 496 $-502$.

Butt MN, Donart GB, Southward MG, Pieper RD, Mohammad N. 1993. Effect of defoliation on plnat growth of Napier grass. Trop. Sci., 33: $111-120$.

Da Silveira MCT, Junior DN, Da Cunha BAL, Difante GS, Pena KS, DaSilva SC and Sbrissia AF. 2010. Effect of cutting interval and cutting height on morphologenesis and forage acumulation of guinea grass (Panicum maximum). Tropical grass land. $44: 103-108$.

Nyambati EM, Muyekho FN, Ongijo E and Luswiti CM, 2010. Production, Characterization and Nutritionla Quality of Napier grass cultivations in Western Kenya. African journal of plant Sci: 4 (12): 496 - 502.

Purwantari ND, dan Sajimin. 2009. Pengembangan Tanaman Pakan Ternak untuk Mendukung Usaha Sapi Perah. Laporan Penelitian TA 2009. Pusat Penelitian dan Pengembangan Peternakan, Bogor.

Purnomo D dan Sitompul SM. 2006. Irradiasi pada system agroforestri berbasis jatidan pinus serta pengaruhnya terhadap pertumbuhan tanaman kedelai. BiodiversitasVol 7(3). P $251-255$.

Perhutani 2009. DephutTawarkan HPH Sapi. www:// www.agroindustr.co.id /dephut-tawrka. Akses : 27/10/2011.

Senjaya YA dan Surakusumah W. 2010. Potensi Ekstrak daun Pinus (Pinus merkusii Jungh et de Vriese) sebagai bioherbisida penghambat perkecambahan Echinochloa colonum L. dan Amaranthus viridis. 
http://file.Upi.edu/ direktori/ D.FPmipa/ jur. pend. biologi.

Siregar ME. 1991. Kebutuhan pupuk untuk pengembangan tanaman makanan ternak. Prosiding Lokakarya Nasional Efisiensi penggunaan pupuk V. Puslitanak Bogor. P: 469 - 492.

Taiz L and Zeiger E. 1991. Plant Physiology. In: Senjaya, Y.A dan W. Surakusumah. 2010. Potensi ekstrak daun pinus (Pinus merkusi Jungh.et de Vriese) sebagai bioherbisida penghambat perkecambahan Echinochloa colonum L dan Amaranthusviridis. Laboratorium Ekologi FMIPA Universitas Pendidikan Indonesia.
Bandung. http://file.upi.edu/direktori/D.FMIPA/ jur.Pend.Biologi. acces 12-12-2010.

Schmidt FH and Ferguson JHA. 1951. Rainfall Types Based on wet and dry period. Rotation For Indonesia with Western New Guinea Verh. No.42. pp 1-77.

Suarna, IW. Partama, IBG, Duarsa MAP. 1994. Growth and production of Panicum Buffle and Heteropogon at various water availability fluctuation. Proceeding at the 7" AAP Animal Science congress held in Bali Indonesia. Juli 11 - 16. Vol II: 507 - 508. 